MACRÓFAGOS REGENERATIVOS: UMA NOVA ESPERANÇA PARA CARDIOMIOPATIA

\title{
REGENERATIVE MACROPHAGES: A NEW HOPE FOR CARDIOMYOPATHY
}

\author{
PUTRANTO, Terawan Agus ${ }^{1 *}$., IKRAR, Taruna²., WASKITO, Pujo ${ }^{3}$ \\ ${ }^{1}$ The Indonesia Army Medical Sciences Institute (THIAMSI), Central Jakarta, Indonesia. \\ 2,3 RSPAD Gatot Subroto, Central Jakarta, Indonesia. \\ * Corresponding author \\ e-mail: terawan@rspadgs.net
}

Received 13 June 2020; received in revised form 29 June 2020; accepted 06 July 2020

\section{RESUMO}

Globalmente, as doenças cardiovasculares (DCV) são a principal causa de morte. Prevê-se que 23,6 milhões de pessoas morrerão em 2030 tendo como causa principalmente derrames e ataques cardíacos. Este estudo teve como objetivo investigar o novo tratamento da cardiomiopatia, uma doença cardiovascular que dificulta o fornecimento de sangue do coração para o corpo e pode causar insuficiência cardíaca. Embora o tratamento tradicional se concentre na reabilitação cardíaca, incluindo exercícios de aconselhamento e prescrições de estilo de vida, cirurgia na artéria coronária e medicamentos para aumentar o fluxo sanguíneo, o uso de células terapêuticas é uma nova forma para lidar com doenças cardiovasculares e infarto do coração. Pretende substituir efetivamente ou regenerar as células cardíacas mortas ou danificadas, de forma eficaz, como a principal vantagem deste tratamento. O uso de método alternativo para tratar as doenças cardiovasculares tem alto valor potencial, conforme encontrado no método de imunoterapia através do uso de "macrófagos regenerativos". Trata-se de um estudo qualitativo de pesquisa de relato de caso em que fornece uma exploração do fenômeno ou oportunidade de compartilhar esforços para intervir anteriormente na saúde de um único paciente com recursos de saúde não relatados. O resultado deste estudo mostrou que um homem de 71 anos foi hospitalizado no Hospital Central do Exército de Gatot Soebroto, em Jacarta, na Indonésia, pelo diagnóstico de doença arterial coronariana. Ele apresentou tosse crônica e edema periférico. Negava síncope, dispnéia, náusea, vômito e diaforese. A aplicação da ecocardiografia referente ao tratamento anterior indicou disfunção diastólica, hipocinesia do ventrículo esquerdo e hipertrofia ventricular esquerda com $44 \%$ de baixa ejeção na fração. Após a vacinação da terapia com Macrófagos Regenerativos (ReM), foram observadas melhorias significativas nos parâmetros ecocardiográficos, com cinética normal, fração de ejeção melhorada e disfunção diastólica que aumentou para $56 \%$. Significativamente, os macrófagos regenerativos podem ser uma opção de imunoterapia em pacientes com cardiomiopatias com baixo risco de tratamento eficaz.

Palavras-chave: Macrófagos Regenerativos, Cardiomiopatia, Ecocardiografia, Fração de Ejeção.

\section{ABSTRACT}

Globally, cardiovascular diseases (CVD) are the number one cause of death. It is predicted that 23.6 million people will die from it by 2030 , mainly caused by strokes and heart attacks. This study aimed to investigate the new treatment of cardiomyopathy, a cardiovascular disease that hinders blood supply from the heart to the body and can cause heart failure. While the traditional treatment focus on cardiac rehabilitation, including lifestyle counseling and prescription exercise, surgery on coronary bypass artery, and medication of increasing the flow of blood, the use of therapeutic cells is a new way to deal with cardiovascular diseases and heart infarction. It intends to effectively replace or regenerate dead or damaged heart cells, as the main advantage of this treatment. The use of alternative methods to treat cardiovascular diseases has high potential value, as found in the immunotherapy method through the use of "regenerative macrophages." This study is a qualitative case report research study which provides an exploration of phenomenon or opportunity of sharing efforts to intervene single patient's health with unreported health features previously. The result of this study showed that a 71 years old man was hospitalized in Gatot Soebroto Central Army Hospital Jakarta, Indonesia, by the diagnosis of coronary artery disease. He presented for chronic cough and peripheral edema. He denied syncope, dyspnea, nausea, vomiting, and diaphoresis. The application of echocardiography regarding the previous treatment indicated diastolic dysfunction, left ventricle hypokinesis and left ventricular hypertrophy with $44 \%$ of low ejection on the fraction. After the vaccines of Regenerative Macrophages (ReM) therapy were given to the patient, significant improvements in the echocardiography parameters were observed, with normal kinetics, improved ejection fraction, and diastolic dysfunction increased to $56 \%$. Significantly, regenerative macrophages could be an option of immunotherapy in patients with cardiomyopathies with low risk of effective treatment further. 
Keywords: Regenerative Macrophages, Cardiomyopathy, Echocardiography, Ejection Fraction.

\section{INTRODUCTION:}

As the leading cause in over budgeting for universal coverage in terms of health blanket insurance in developing countries, cardiovascular disease (CVD) gets its vital concern for years. Its symptoms appear mostly at middle age along with pathological features called atherosclerosis. Acute coronary and cerebrovascular events frequently suddenly occur, and are often fatal before medical care can be given. Modification of treatment risk factors has been shown to reduce mortality and morbidity in people with diagnosed and undiagnosed cardiovascular disease (CVD). Cardiovascular disease is characterized by its high prevalence as the leading cause of early morbidity in the population (Apetrei-Corduneau, Fildan, Radu, Statescu, Nemteanu, Lupusoru., 2020., Diaconu, 2019).

The devitalizing impediment found in CVD is usually seen in middle-aged or older adults and women. However, atherosclerosis, the principal pathological process leading to coronary artery disease, cerebral artery disease, and peripheral artery disease, begins early in life and progresses gradually through adolescence and early adulthood (Berenson et al., 1989., Zieske, Malcom, \& Strong, 2002., Mendis et al., 2005).

Several factors cause an increased risk of the threat of someone suffering from cardiovascular disease, one of which is the rate of development of atherosclerosis. It is exacerbated by smoking habits, improper dietary patterns without being balanced with physical activity, diabetes, dyslipidemia, and hypertension which are risk factors as triggers for the blockage of blood flow, and narrowing of blood vessels because of continued effects of the development of atherosclerosis which can trigger severe illness such as; myocardial infarction, stroke, transient cerebral ischemic attacks, and angina.

There are some ways of therapy to halt cerebral, peripheral vascular, and coronary events without putting aside aspects of intensity and particular aversive action to predict any risks of vascular features as the guidance leading for decision.

The most current treatment applied for most patients with cardiovascular diseases is by having healthy living behavior continued by taking medicine when needed to reduce the occurrence of strokes and heart attacks which directly affect the reduction in mortality, morbidity, and premature disability. Nearly most people are unaware or aware of their status against potential CVD attacks. With self-screening, it will be able to detect several risk factors that arise, such as blood pressure, blood glucose, and blood lipids (Tunstall-Pedoe, 2003). By the result of screening for the risk of their status in CVD, it can be used as a guide for further action, whether in the form of a healthy lifestyle program related to the type of food intake, or physical exercise that can cure patients at an affordable cost. (World Health Organization, 2003).

The pattern of prevention of CVD by being associated with existing risk factors will be very significant in the accuracy of the diagnosis and clinical action taken on patients. Other considerations, such as the type of food intake and physical body processing, should also not be ruled out because it is related to the type, dose, and time of medication given to patients for continued risk control. Efficiency and effectiveness in managing patients become a necessity amid limited resources through a risk stratification approach (Integrated cardiovascular management, 2002). Administration of drugs in patients with diastolic blood pressure above $90 \mathrm{mmHg}$, systolic levels above $150 \mathrm{mmHg}$, and blood cholesterol levels above $5.0 \mathrm{mmol} / \mathrm{l}$ can reduce the risk of cardiovascular disease by one third to a quarter (Lewington., \& Clarke, 2005; Baigent et al., 2005., Turnbull, 2003., Sever, 2003., Lewington et al., 2002., Lawes et al., 2003., \& LaRosa, He, Vupputuri, 1999). To anticipate cardiovascular disease contributed by blood compulsion is in proceeding toward of overall risk of $5-8 \mathrm{mmHg}$ (diastolic), $10-15 \mathrm{mmHg}$ (systolic) and included blood cholesterol at approximately $20 \%$ integrated medication with antihypertensive and statins, then cardiovascular disease morbidity and mortality would be reduced by up to $50 \%$ (Wald ., \& Law, 2003). People at very high CVD risk would bring more positive and significant results in the perspective of total circumstances as the declining risk of CVD toward higher diagnostic risk (MacMahon., \& Rodgers, 1993).

However, the disadvantages of this regular or traditional treatment are at the cost of medicines. It is a significant component of total preventive health care costs, and particularly relevant to base drug treatment decisions on an individual's risk level, and not on arbitrary criteria, such as the ability to pay, or on comprehensive 
preventive strategies. Also, the cumulative risk of CVD, which uses risk scoring methods, has been shown to be both expensive and less effective.

For people or patients who have a history or record of transient ischemic attacks, myocardial infarction, a stroke, which generally begins with atherosclerosis symptoms, it becomes an essential record in efforts to obtain other treatment methods. This is crucial because there is a very high risk of coronary, peripheral, and cerebral artery stability. The patient's history of the tendency of CVD symptoms will affect the type of care given to reduce mortality and or the cost of care for patients who recover. Stratification risk charts are unnecessary to arrive at treatment decisions for these categories of patients. They require another option of medical treatment, which not only to have healthy food but also an intervention in how to stop smoking, achieve ideal weight and have regular body exercise, which is highly cost and consuming much time (World Health Organization, 2003; Tunstall-Pedoe, 2003).

Therefore, this study aimed to investigate the new treatment of cardiovascular disease as occurred in cardiomyopathy in a less expensive and complicated procedure to reduce the risk of death to respond to the patients' needs for medication.

\section{REVIEW OF LITERATURE:}

\subsection{Macrophages}

Macrophages were first discovered by llya Metchnikoff in the late 19th century and are conserved phagocytes evolutionary that evolved more than 500 million years ago as the system against occurred injury (Yonggang, Merry., et al., 2018). They belong to white blood cell digests cancer cells, foreign substances, cellular debris, and microbes, and any other substances that have specific proteins for the body's health on its surface, namely as phagocytosis.

They are found basically in all tissues by amoeboid movements to patrol for potential pathogens. The forms of these macrophages are varied (with various names) along the body (for example, Kupffer cells, microglia, histiocytes, alveolar macrophages) as part of the system in mononuclear phagocyte. They keep up their essential role as the protection by the mechanism of defense both in innate immunity and adaptive immunity by involving other immune cells such as lymphocytes (Yonggang, Merry., et al., 2018., Gordon, 2007., Epelman, Lavine, Randolph, 2014).
In addition, to improve stimulation and inflammation towards the immune system, they can be functioned as reducing reactions on immunity and anti-inflammatory by releasing cytokines Ben-Mordechai., Palevski., GlucksanGalnoy., Elron-Gross., Margalit., Leor, 2015). Macrophages which can lead into inflammation are labeled as $\mathrm{M} 1$, while others heading to declining on inflammation and supporting the repair on tissues are tagged as M2.10 The main difference between two of them are found in their metabolism where M1 includes unique ability to metabolize arginine into nitric oxide "killer" molecules. At the same time, M2 can metabolize arginine into ornithine "repair" molecules (Gombozhapova, Rogovskaya, Shurupov., et al., 2017., Martine., Sica, Mantovani., \& Locati, 2008).

\subsection{Physical Examination}

It is exposed that around 21 micrometers $(0,00083$ in) in the diameter of human macrophages are resulted by the categorization of monocytes' tissue (Gombozhapova, Rogovskaya, Shurupov., et al., 2017., Martinez., Sica, Mantovani., \& Locati, 2008). By applying cytometry flow or immune histochemical staining with a particular expression of their proteins such as lysozyme M, MAC-1 / MAC-3, and CD68, CD14, CD40, CD11b, CD64, F4 / 80 (rat) / EMR1 (human) (Pelegrin., \& Surprenant, 2009). These characteristics are mentioned in table 1 (Bai, Adriani, Dang., et al., 2009., Colin, ChinettiGbaugidi., \& Staels, 2014). M2a and M2c macrophages are mainly undertaking to coordinate the response of adaptive, while M2b macrophages suppress (inflammation, fibrosis) and tissue remodeling (Lindset., \& Saucerman, 2016).

\subsection{Parameters Checked}

The parameter or macrophages are the total number of viable cells, proportion of viable cells, proportion of TLR 2- Positive cells, the proportion of CD 274 positive cells, the balance of CD 80 positive cells, the proportion of CD11c positive cells. The required review result of each: the total number of viable cells $\geq 1 \times 10^{6}$ cells proportion of viable cells $>50 \%$ proportion of TLR 2- Positive cells $\leq 40 \%$, the proportion of CD 274 positive cells $\geq 50 \%$, the proportion of CD 80 positive cells $\leq 75 \%$, the proportion of CD11c positive cells $\geq 90 \%$.

Cardiomyopathy patient that refused CABG and PCl come to cell cure. The doctor that cell-cure qualified takes a medical history and do 
a physical examination. Physical examination consists of head to toe checking and vital sign. After that, the patient received a series of examinations in the laboratory, such as complete blood count, liver function, renal function, and immunoserology (HIV, Hep B, and Hep C). After that, the cell cure takes whole blood with two techniques. First, it was done manually (without the device). The whole blood had been taken as much as $9 \mathrm{cc} \times 23$ tubes. Total whole blood is 207 cc. Second, it was used leukapheresis to get monocyte from the leukocyte. After that, it was processed in a clean-room. To get the monocyte cell, a labeling system was used with a flow cytometer. Similar things to the monocyte that manipulated become macrophages were done. It was also used as a labeling system with flow cytometry until it gets macrophages that were wanted.

In contrary to recently used treatments, Therapeutic methods immunotherapy have the significant possibility to encourage and promote endogenous mechanisms of cardiac repair and give the main element for full regeneration of damaged heart tissue (Lemcke., Voronina., Steinhoff., et al., 2018).

Most of the macrophages are located in the strategic point where the accumulation of microbial invasion may take place along together in the mononuclear phagocyte system. Each type of macrophage, determined by its location, has a specific name (Kara, Spiller., \& Timothy, 2017). Macrophages can express the function of paracrine within an organ that is specific to the role of that organ. The viable cells of ReM that needed to stimulate a robust inflammation immune response is $\geq 1 \times 10^{6}$ cells). ReM was administrated by intravenous therapy (IV) (Figure 1).

Macrophages are widely distributed in the human body. Macrophages play a role in the inflammatory process as the body's reaction to foreign matter or microbes. In neoplastic growth, macrophages are found in the extracellularspace. These macrophages in the extracellular spaceare known as tumor-associated macrophages (TAMs). For years it has been known that TAMs are the main cellular component of cancer in humans. However, it is still difficult to understand how the process and mechanism. Macrophages phagocytose pathogens, dead cells, and some elements in the matrix extracellular. Macrophages also function to regulate organ and homeostasis remodeling. During tissue regeneration or healing, macrophages stimulate angiogenesis and facilitate tissue remodeling by protease secreting and growth factors. Macrophages in tissue can be identified by the expression of several markers; in humans, the marker is CD68. The majority of macrophages are in the area perivascular wound healing area

In some cases, the pathogenesis of cardiomyopathy remains unknown and thus is classified into idiopathic cardiomyopathy. Previously, ischemic cardiomyopathy was also included in the category of cardiomyopathy but the current consensus separates it into coronary heart disease. The causes of cardiomyopathy are various, but the most common is inherited genetic factors, both autosomal dominant and recessive, and related to sex chromosomes. Other causes include toxins related to alcohol use disorder, cocaine and amphetamine use disorder, or the use of chemotherapy drugs.

The patient wanted an advance therapy, but he refused coronary artery bypass graft (CABG). The doctors want to increase survival rate with gave especially regenerative macrophages vaccine therapy. After this intervention approach, the patient had been checked by echocardiography. The result was significantly changed and increased. Echocardiography showed diastolic dysfunction, left ventricular hypertrophy, ejection fraction, and normokinetic, from $44 \%$ became $56 \%$.

Macrophages can migrate out of the vascular system by crossing cell membranes from capillaries and entering the area between cells that are being targeted by pathogens. Neutrophils are the most efficient phagocytes followed by macrophages and can digest large amounts of bacteria or other cells. Binding of bacterial molecules to the surface receptors of macrophages triggers the process of swallowing and destroying bacteria through "respiratory attack", causing the release of reactive oxygen species (ROS). The pathogen also stimulates macrophages to produce chemokines, which call other phagocytic cells around the infected area to give influence on the development of chronic inflammatory diseases such as cardiomyopathy.

\section{MATERIALS AND METHODS:}

It is a qualitative case report research study where provides an exploration of phenomenon or opportunity of sharing efforts to intervene single patient's health with unreported health features previously. As a qualitative methodology, it encompasses a great deal more complexity and incorporates of data combined in creative ways. It provides richness and depth description that helps 
to understand the situation and whether findings from the case are applicable of a report from a 71 years old man by the diagnosis of coronary artery disease as the sample to be reported. The patient presented for chronic cough and peripheral edema of left ventricular diastolic function.

His parents and/or relatives in this participant study were informed related to the nature of the study and signed a consent for taking part in the study. It was approved by the Ethics and Bioethics Committee of the National Health Ministry of Indonesia and according to Helsinki Declaration (1975).

\section{RESULTS AND DISCUSSIONS:}

According to the survey in 2013 to 2016 by National Health and Nutrition Examination, the generality of cardiovascular diseases (CVD), adjusting stroke, coronary heart disease (CHD), hypertension, and heart failure (HF) in $\geq 20$ years of age by category of adults is $48.0 \%$ (121.5 million in 2016) and uplifting with progressing age in both men and women. Using Healthcare Cost and Utilization Project (HCUP) data for cardiomyopathy in 2014, there were 16,000 hospitalizations in America. Its system to be not transparent and understudied as underlying the changes that occurred (Roytberg, Sharkhun, Platonova., \& Stepanova, 2020).

It showed that cardiomyopathy became the main diagnosis of 966.000 cardiovascular diseases, mostly found. Data from the National Heart, Lung, and Blood Institute, sponsored by some institutions covering; Chicago Heart Association Detection Project in Industry, ARIC (Atherosclerosis Risk in Communities Study), and CHS (Cardiovascular Health Study) indicate that incidence of HF approaching population to 21 per 1000 after the age of 65 years old (Benjamin. et al, 2019).

The cells in heart muscle cells or myocardiocytes are muscle cells that form heart's muscle consisting of sarcomeres. They expose something in common as found in skeletal muscle cells that may have as many as four nucleus producing adenosine triphosphate quickly, making it very resistant to fatigue.

The necrosis in cardiomyocyte is caused by external factors of cells or tissues, such as infection, toxins, or trauma that result in irregular digestion of cell components. Cellular death due to necrosis does not follow the apoptotic signal transduction pathway; various activated receptors result in loss of cell membrane integrity and uncontrolled release of cell death products into the extracellular space. This event triggers an inflammatory response in the surrounding tissue, attracting leukocytes and phagocytes that are close to killing death cells with phagocytosis. However, destructive microbial agents released by leukocytes will create additional damage to the surrounding tissue. This extra damage is excessively inhibiting the healing process. Thus, untreated necrosis results in piles of tissue and debris that decompose dead cells at or near the location of cell death.

Macrophages originate from monocytes found in the blood circulation, which become mature and differentiated then migrate to the tissue. They can be found in large numbers, especially in connective tissue, such as those connected to the digestive tract, in the lungs (in body fluids or alveoli), and along certain blood vessels in the liver such as Kupffer cells, and in the entire spleen where the cells are damaged blood is recycled out of the body. This type of macrophage is called a resident who is fully differentiated. They are an integral part of innate immune response and leads to the main interest of research scientifically. As the key to respond inflammation, macrophages perform antigens on the surface on their cell by major histocompatibility complex II (MHC II) that result in cellular debris on resorption, anti and pro factors on inflammatory, and formation of granule tissue. They could also function as healing and remodeling the cardiac through growth factors, apoptosis, proteases, and proliferation (Gombazhapova, Rogovskaya, Shurupov., et al., 2017., Yona, Kim, Wolf, Mildner, Varol, Breker., et al., 2013).

The plasticity of myocardial infarction in macrophages and monocytes' function plays an essential role to control cardiac remodeling, inflammation, and acute coronary healing (Furth., \& Cohn, 1968., Takahashi, 1994., Yona, Kim, Wolf, Mildner, Varol, Breker., et al., 2013., Sica., \& Mantovani, 2012).

A 71 years old man was taken to Gatot Soebroto Central Army Hospital Jakarta, Indonesia, by the diagnosis of coronary artery disease. The patient presented for chronic cough and peripheral edema. He denied syncope, dyspnea, nausea, vomiting, and diaphoresis. His medical history was notable for hypertension and diabetes mellitus type II. On admission, the patient was afebrile; his heart rate was 86 beats per minute, respiratory rate was 20 breaths per minute, blood pressure was 140/90 $\mathrm{mmHg}$, oxygen saturation was $98 \%$ on room air. He was alert and in no acute distress, without notable 
jugular distension. Cardiac examination revealed normal S1 and S2, with no murmur or extra heart sounds. His lungs are clear to auscultation bilaterally. Peripheral edema was noted.

The patient performed a series of investigations covering; echocardiography, chest $\mathrm{X}$-ray, and electrocardiography. Chest X-ray was abnormal with CTR $50 \%$ (Cardiothoracic ratio), fibrosis in right basal lung, without infiltrate, and haziness in the costophrenic angle, with differential diagnosis of pleuritis. The electrocardiogram showed multiple ventricular extrasystoles. The echocardiography performed diastolic dysfunction (impaired relaxation type), hypertrophy on left ventricular, and hypokinetic on the left ventricle with low ejection fraction $44 \%$ (Figure 1). The diagnosis of hypertrophic cardiomyopathy was established.

The patient refused the coronary artery bypass graft (CABG). Furthermore, the doctors want to increase survival rate with gave especially Regenerative Macrophages vaccines therapy. After this intervention approach, the patient had been checked by echocardiography. The result was significantly changed. Echocardiography showed left ventricular hypertrophy, normokinetic, diastolic dysfunction, and ejection fraction became $56 \%$.

In this case, the patient treated by the method of immunotherapy was chosen by regenerative macrophages of human origin from the patient. In regenerative macrophages of human origin vaccine therapy, blood's monocytes were split out from others' components and programmed as regenerative macrophages of human origin. The human macrophages cultures were established by treating peripheral blood monocytes and complete for four days.

The measurement of pulse wave Doppler sample volume on the transmittal inflow shows an $\mathrm{E} / \mathrm{A}$ ratio, a marker of the function of the left ventricle of the heart. It represents the ratio of peak velocity blood flow from left ventricular relaxation in early diastole (the $E$ wave) to peak velocity flow in late diastole caused by atrial contraction (the A wave), of less than 1 , showing a grade 1 diastolic dysfunction (Figure 2 ).

Visualization of the left ventricle in PLAX, Mmode at the mitral tips level that works by transducering image marker directed toward the patient's right ear and the sound beam directed to the spine. Slight adjustments in angle and rotation maybe necessary to demonstrate all the structures for this view optimally, quantify LVEF with the Teicholz equation is $44 \%$, with myocardial thickening as measured by interventricular septum was $13.4 \mathrm{~mm}$ at dialosticand $16.6 \mathrm{~mm}$ at systolic and also $267 \mathrm{~g} / \mathrm{m} 2$ in LV mass (Figure 3).

Quantitative assessment of Right Ventricular function with Tricuspid Annular Plane Systolic Excursion (TAPE) was $23.7 \mathrm{~mm}$, reveal the normal value of $\mathrm{RV}$ function $(>20 \mathrm{~mm}$ means RV EF >50\%) (Figure 4). The left ventricular ejection fraction increased with the calculation of the Teicholz formula obtained by 56\% (Figure 5).

By using RPMI-1640 (Lonza), adherent cells were accomplished with additives with $5 \%$ $\mathrm{CO} 2$ at $37^{\circ} \mathrm{C}$. The recombinant of human macrophage colony-stimulating factor $(50 \mathrm{ng} / \mathrm{mL})$ was used to gain M2-like macrophages and the deprivation conditions of its serum (autologous plasma in low percentage). PBS (Phosphate Buffer Saline) is used to have macrophages in four days, followed by EDTA (Lonza), washed with Triple Expres Tripsine (Gibco), and counted in 4 days (Table 1). M2-like macrophages were generated and resuspended in $2 \mathrm{~mL}$ of $3 \times 10^{7}$ sodium chloride $0.9 \%$ plus Albumin $20 \%$ and the end infused into IV of the patient. Therapeutic methods immunotherapy and their combination are the major promising strategies. The modes of immunotherapy were classified as conventional and rush immunotherapies. In contrast to currently applied treatments, immunotherapy has the potential to stimulate and support endogenous mechanisms of cardiac (Table 2).

\section{CONCLUSIONS:}

CVD is characterized by its high prevalence as the leading cause of early morbidity in the population. The suffered patient with cardiomyopathy found no alternative for medication recovery performed positive progress on echocardiography and clinical after treated with immunotherapy by the Regenerative Macrophages vaccine. In some pathological conditions, it has the function to force tissue homeostasis and innate immunity. Macrophages degrade and ingest foreign materials, dead cells, and debris. They support homeostasis by responding to external and internal changes within the body. It is not only as phagocytes, but also repair functions, regulatory, and trophic

\section{REFERENCES:}

1. Apetrei-Corduneau, O., Fildan, P. A., Radu, R., Statescu, C., Nemteanu, R., Lupusoru, C. E. (2020). Cardiovascular Side Effects of 
Neuropsychiatric Medication: An Update. Archives of the Balkan Medical Union, 55(1), 138-145.

2. Bai, J., Adriani, G., Dang, T. M., et al. (2015). Contact-dependent carcinoma aggre-gate dispersion by $\mathrm{M} 2 \mathrm{a}$ macrophages via ICAM-1 and $\beta 2$ integrin interactions. Oncotarget, 6(28):25295-25307.

3. Baigent, C et al., (2005). Cholesterol Treatment Trialists' (CTT) Collaborators. Effi cacy and safety of cholesterollowering treatment: prospective meta-analysis of data from 90,056 participants in 14 randomised trials of statins. Lancet, 366(9493):1267-78

4. Berenson, G. S. et al. (1989). Risks factor in early life as predictors of adult heart disease: the Bogalusa heart study. American Journal of Medical Science, 298(3), 213-237.

5. Benjamin, et al. (2019). Statistic update Heart Disease and Stroke Statistics. American Heart Association. Report number: 139.

6. Ben-Mordechai, T., Palevski, D., GlucksamGalnoy, Y., Elron-Gross, I., Margalit, R., Leor, J. (2015). Targeting macrophage subsets for infarct repair. J Cardiovasc Pharmacol Ther, 20(4): 36-51.

7. Colin, S., Chinetti-Gbaguidi, G., Staels, B. (2014). Macrophage phenotypes in atherosclerosis. Immunol Rev, 262(1):153166.

8. Diaconu, C. (2019). Is the Implication of Intestinal Microbiota in Cardiovascular. Archives of the Balkan Medical Union, 54(4), 609-611.

9. Epelman, S., Lavine, K. J., \& Randolph, G. J. (2014). Origin and functions of tissue macrophages. Immunity, 41(10): 21-35.

10. Furth, R., Cohn, Z. A. (1968). The origin and kinetics of mononuclear phagosytes. $\mathrm{J}$ Exp Med, 128(4): 15-35.

11. Gombazhapova, A., Rogovskaya, Y., Shurupov V, et al. (2017). Macrophage activation and polarization in post-infarction cardiac remodeling. Journal of Biomedical Science, 24(6): (13-19). Available from: doi: 101186/s12929.017.0322.3.

12. Gombozhapova, A,, Rogovskaya, Y., Shurupov, V., et al. (2017). Macrophage activation and polarization in post-infarction cardiac remodeling. J Biomed Sci, 8(24):1319.

13. Gordon, S. (2007). The macrophage: past, present and future. Eur J Immunol, 37(2): 917.

14. Integrated Management of Cardiovascular risk. (2002). Report of a WHO meeting. Geneva, World Health Organization.

15. Kara, L., Spiller \& Timothy, J. Ko. (2017). Macrophage-based therapeutic strategies in regenerative medicine. Adv Drug Deliv Rev, 122(7): 74-83. Available from: doi :10.1016/ j.addr.2017.05.010.

16. Lawes, C. M. et al., (2003). Asia Pacific Cohort Studies Collaboration. Blood pressure and cardiovascular disease in the Asia Pacific region. J Hypertens, 21(4):707-716.

17. Lemcke, H.,Voronina, N., Steinhoff, G., et al. (2018). Recent Progress in Stem Cell Modification for Cardiac Regeneration. Hindawi Stem Cells International, 3(6): 1-22. Available from: doi: org/10.1155/2018/1909346.

18. LaRosa, J. C., He, J., \& Vupputuri, S. (1999). Effect of statins on risk of coronary disease: a meta-analysis of randomized controlled trials. JAMA, 282(24):2340-2346.

19. Lewington, S. et al., (2002). Prospective Studies Collaboration. Age-specific relevance of usual blood pressure to vascular mortality: a meta-analysis of individual data for one million adults in 61 prospective studies. Lancet, 360(9349):1903-1913.

20. Lewington, S., \& Clarke, R. (2005). Combined effects of systolic blood pressure and total cholesterol on cardiovascular disease risk. Circulation, 112:3373-3374.

21. Lindsey, M. L., Saucerman, J. J., DeLeonPennell, K.Y. (2016). Knowledge gaps to understanding cardiac macrophage polarization following myocardial infarction. Biochim Biophys Acta, 186(222): 88-92.

22. MacMahon, S., \& Rodgers, A. (1993). The effects of blood pressure reduction in older patients: an overview of $\mathrm{fi}$ ve randomized controlled trials in elderly hypertensives. Clin Exp Hypertens, 15(6):967-978.

23. Martinez, F. O., Sica, A., Mantovani, A., Locati, M. (2015). Macrophage activation and polarization. Front Biosci, 13(4): 53-61.

24. Mendis, S. et al. (2005). For the patholobiological determinants of artherosclerosis in Youth (PBDAY) research group. Artherosclerosis in children and young adults: an overview of the World Health 
Organizations (WHO and International Society and Federation of Cardiology Study on Pathobiological Determinants of Artherosclerosis in Youth Study (1985-1995). Prevention and Control, 1, 3-15.

25. Pelegrin, P., \& Surprenant, A. (2009). Dynamics of macrophage polarization reveal new mechanism to inhibit IL-1beta release through pyrophosphates. EMBO J, 28(21):14-27.

26. Roytberg, G. E., Sharkhun, O. O., Platonova, O. E., \& Stepanova, A. A. (2020). The positron emission tomography in early diagnostics transtornos metabolic myocardial disorders in insulin-resistant patient with nonalcoholic fatty liver disease, Periodico Tche Quimica, 17(34), 1026-1032.

27. Sica, A., \& Mantovani, A. (2012). Macrophage plasticity and polarization: in vivo veritas. $\mathrm{J}$ Clin Invest, 8(122): 87-95.

28. Sever, P. S. et al., (2003). ASCOT investigators. Prevention of coronary and stroke events with atorvastatin in hypertensive patients who have average or lower-than-average cholesterol concentrations, in the Anglo-Scandinavian Cardiac Outcomes Trial - Lipid Lowering Arm (ASCOT-LLA): a multicentre randomised controlled trial. Lancet, 361(9364):11491158.

29. Takahashi, K. (1994). Development and differentiation of macrophages and their related cells. Hum Cell, 7(10): 9-15.

30. Tunstall-Pedoe, H. (2003). For the WHO MONICA project, MONICA monograph and multimedia sourcebook. World largest study of heart disease, stroke, risk factors and populations trends. 1979-2002. Geneva. World Health Organization.

31. Turnbull, F. (2003). Blood pressure lowering treatment trialists' collaboration. Effects of different blood-pressurelowering regimens on major cardiovascular events: results of prospectively-designed overviews of randomised trials. Lancet. 362(9395):15271535.

32. Wald, N. J., \& Law, M. R. (2003). A strategy to reduce cardiovascular disease by more than $80 \%$. BMJ. 2003 Jun 28;326(7404):1419. Erratum in: BMJ. 2003 Sep 13;327(7415):586. BMJ. 2006 Sep;60(9):823.

33. World Health Organization. (2003).
Prevention of recurrent heart attacks and strokes in low and middle income populations. Evidence-based recommendations for policy makers and health professionals. Geneva

34. Yona, S., Kim, K. W., Wolf, Y., Mildner, A., Varol, D., Breker, M., et al. (2013). Fate mapping reveals origins and dynamics of monocytes and tissue macrophages under homeostasis, immunity. 6(38): 79-91.

35. Yonggang, M. A., Alan, J., Merry, L. et al. (2018). Cardiac macrophage biology in the steady-state heart, the aging heart, and following myocardial infarction. HHS Public Access, 20(191): 15- 28. Available on: doi: 10.1016/j.trsl.2017.10.001.

36. Zieske, A. W., Malcom, G. T., \& Strong, J. P. (2002). Natural history and risk factors of artherosclerosis in children and youth: the PDYA study. Pediatr Pathol Mol Med, 21(2), 213-237. 


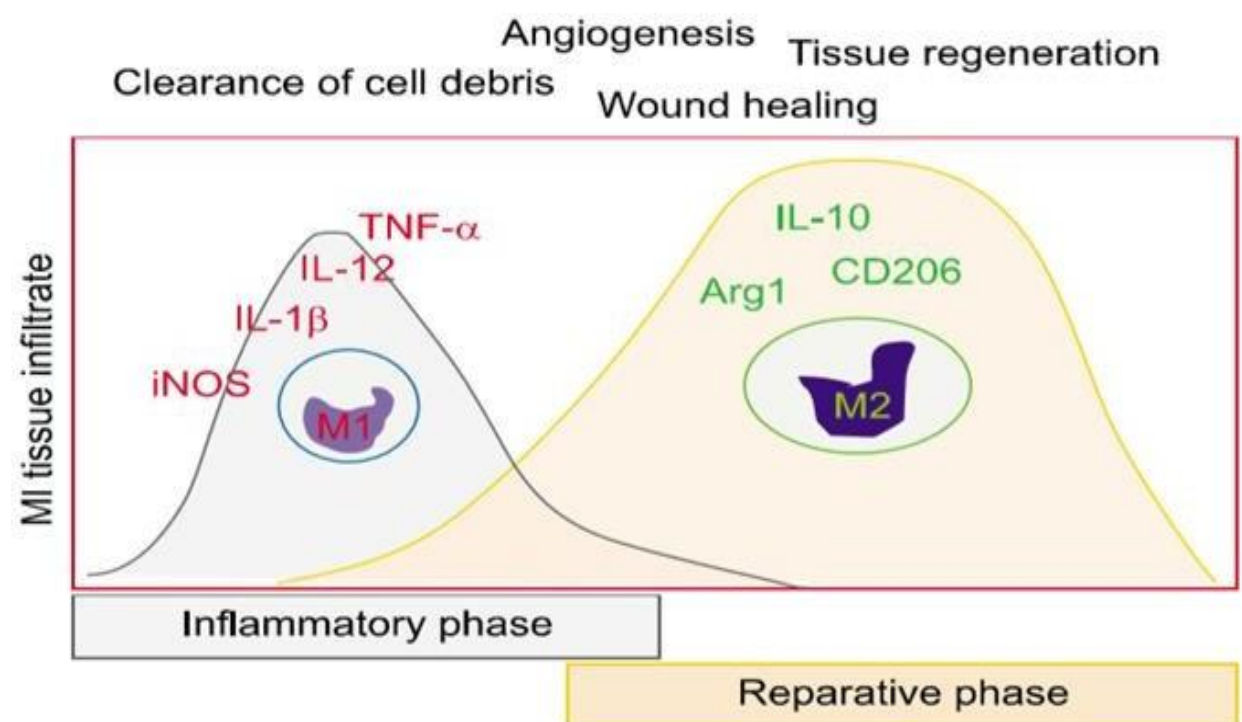

Figure 1. Macrophages function.

Source: Macrophages Clinical and Diagnostic Laboratory Test Result of Gatot Soebroto Central Army Hospital

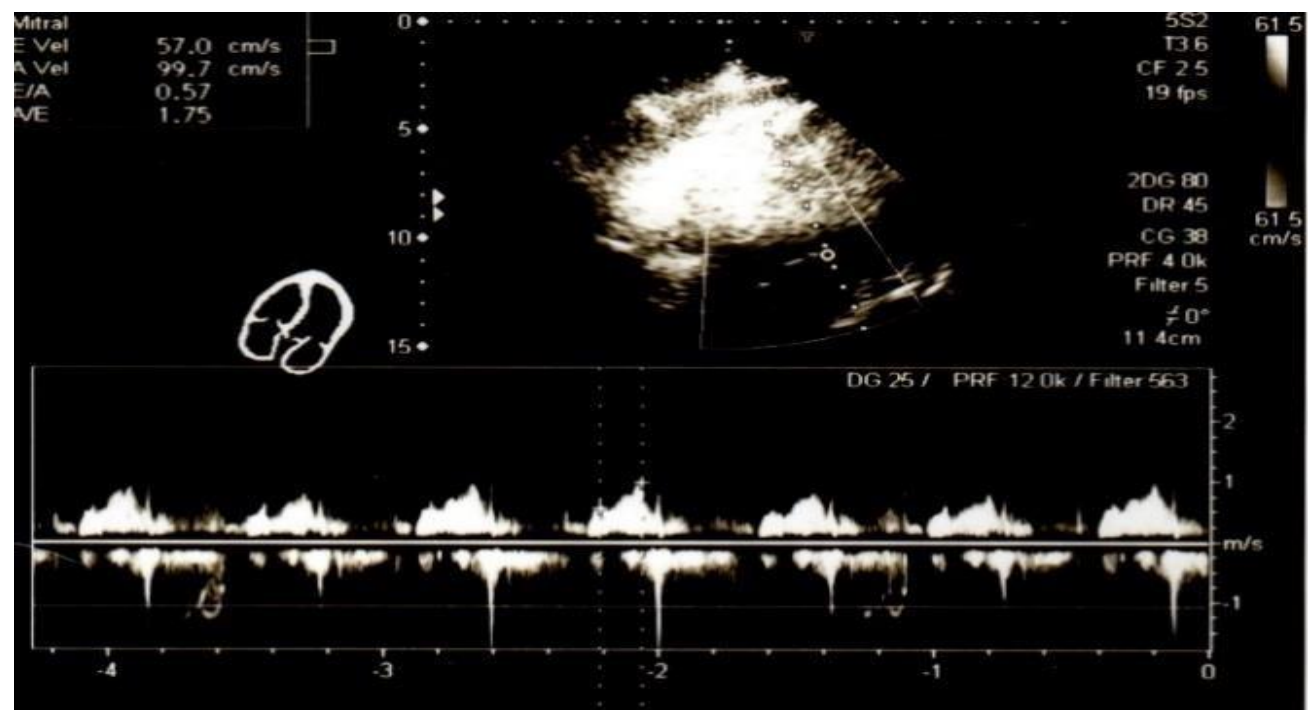

Figure 2. Assessment of left ventricular diastolic function

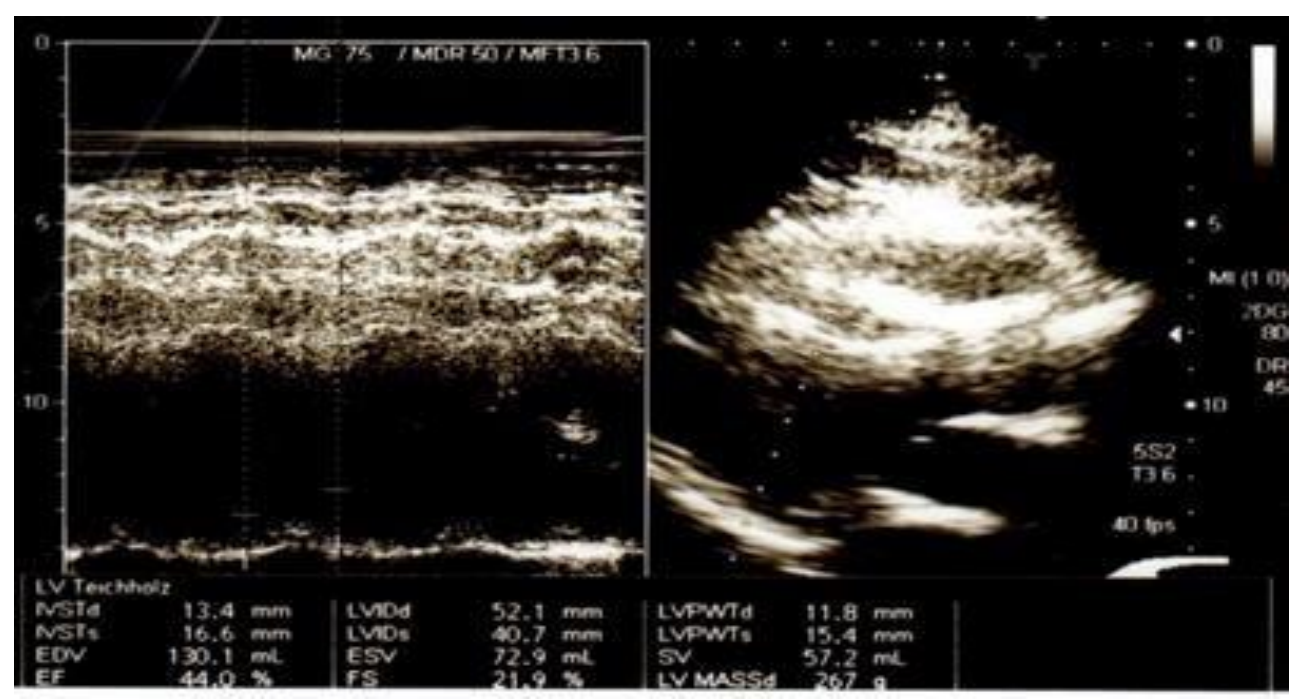

Figure 3. Assessment of left ventricular function

Periódico Tchê Química. ISSN 2179-0302. (2020); vol.17 (n³5) Downloaded from www.periodico.tchequimica.com 


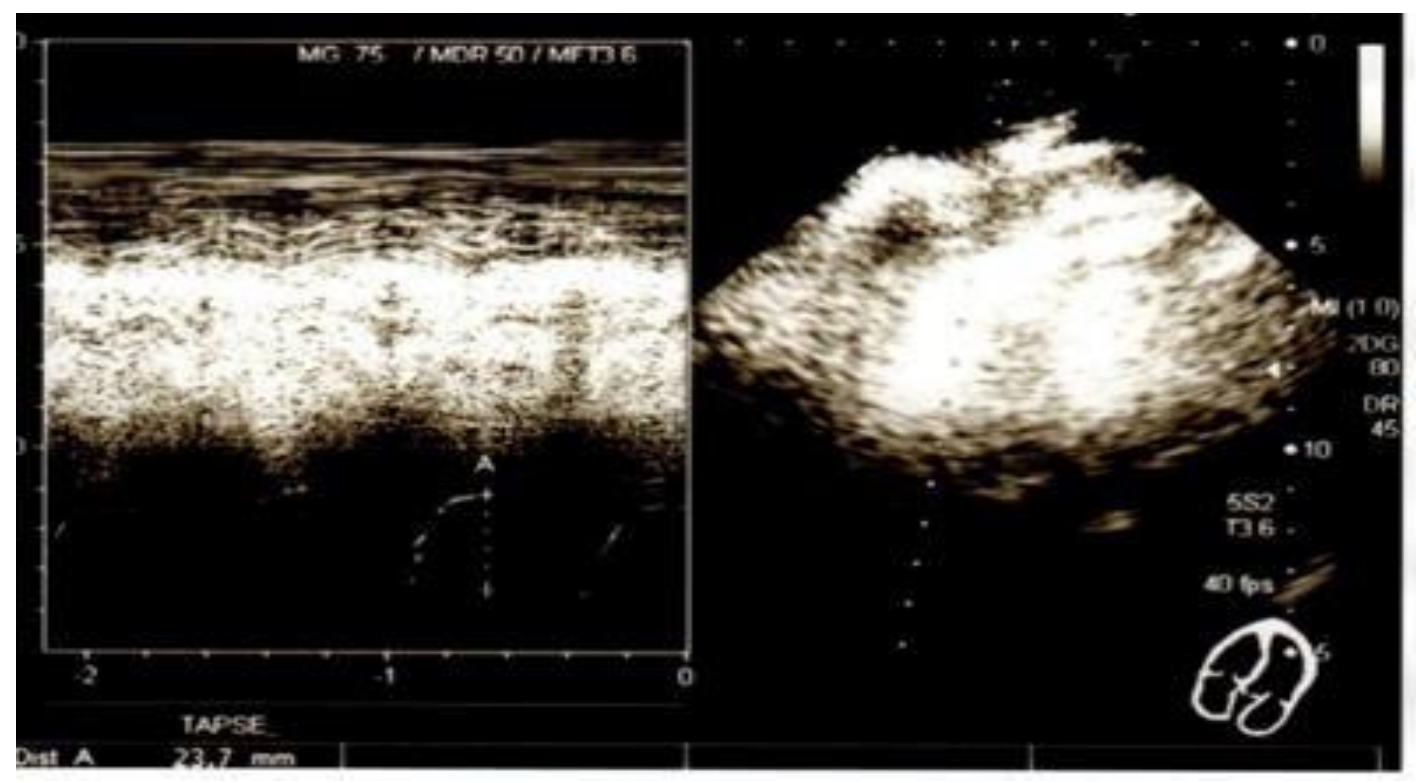

Figure 4. Quantitative assessment of right ventricular function before Cellcure.

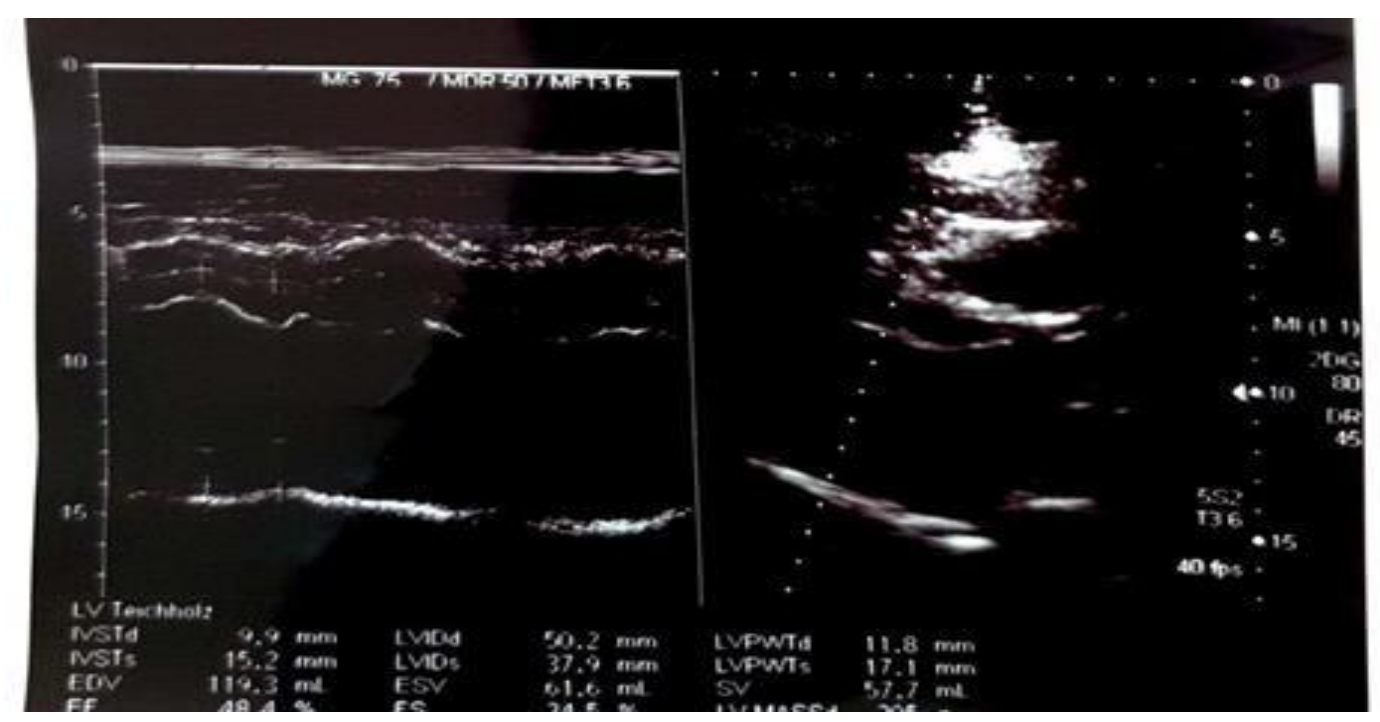

Figure 5. Assessment of left ventricular function after Cellcure.

Table 1. Report of Echo/ Doppler

\section{REPORT OF ECHO/DOPPLER \\ Name : DA \\ Date Birth : : 14-05-1948}

\section{Date Assessment: 11-04-2019 and 28-05-2019}

\begin{tabular}{cc}
\hline $\mathbf{1 1 - 0 4 - 2 0 1 9}$ & $\mathbf{2 8 - 0 5 - 2 0 1 9}$ \\
\hline EF: $44 \%$ & EF: $56,49 \%$ \\
\hline EDD: $52,1 \%$ & EDD: $\mathbf{4 2} \%$ \\
\hline ESD: $40,7 \%$ & ESD: $\mathbf{2 9 , 7} \%$ \\
\hline LVH (+); LV Hypokinetic; Diastolic Disfunction & LVH (+); Normokinetic, Diastolic Disfunction \\
\hline Hyperthrophy Cardiomyopathy & LVH, Diastolic Dysfunction \\
\hline Notes: EF - Ejection fraction; &
\end{tabular}

Notes: EF = Ejection fraction; EDD = End-diastolic diameter; ESD = End Systolic diameter; LVH = Left ventricular hyperthropy; 
Table 2. Characteristics and molecular release from activated macrophages

\begin{tabular}{|c|c|c|c|c|c|}
\hline Subtypes & Inducers & Cell markers & Cytokines & Chemokines & Function \\
\hline \multirow[t]{3}{*}{$\mathrm{Ml}$} & $\begin{array}{l}\text { Ifn-\%, LPS, } \\
\text { Bacteria }\end{array}$ & CCR7, CD25, CD86, & TNF- $\alpha, I L-I ß$, & RANTES, & $\begin{array}{l}\text { Proinflammatory } \\
\text { function }\end{array}$ \\
\hline & GM CSF, oxidative & CD127, MHCIL, ROS, & NO, IP-10. & CCL-8/15/19/20. & $\begin{array}{c}\text { Pathogen clearance, } \\
\text { tissue }\end{array}$ \\
\hline & $\begin{array}{c}\text { fatty acid/LDL, } \\
\text { HMGBI }\end{array}$ & Inos, arginase-2 & IL-6/8/12/15/17/23 & $\begin{array}{l}\text { CXCL- } \\
9 / 10 / 11 / 13\end{array}$ & damage \\
\hline \multirow[t]{2}{*}{$\mathrm{M} 2 \mathrm{a}$} & IL-4, IL13, M-CSF, & CD206, CD209, Fizzl, & IL-4/10/13/33/35, & CCL-8/13/14 & Allergic inflammation \\
\hline & NLRP3 & YmL/2, RELM- $\alpha$, arginase-I & $\begin{array}{l}\text { MMP-9, MMP-14, } \\
\text { IGF-I }\end{array}$ & $\begin{array}{c}\text { CCL- } \\
17 / 18 / 23 / 26\end{array}$ & \\
\hline \multirow[t]{2}{*}{ M2b } & LPS, IL-I B, & CD206, CD209, Fizzl, & IL-10, TGF-B, & CCL-1/20 & $\begin{array}{l}\text { Tissue remodeling, } \\
\text { fibrosis }\end{array}$ \\
\hline & $\begin{array}{c}\text { Immune } \\
\text { complex/IL-Ira }\end{array}$ & YmL/2, RELM- $\alpha$, arginase-I & $\begin{array}{c}\text { CCL-I/20, CXCL- } \\
1 / 2 / 3\end{array}$ & CXCL-1/2/3 & \\
\hline \multirow[t]{3}{*}{ M2c } & $\begin{array}{l}\text { TGF- } ß, I L-10 \\
\text { PGE2 }\end{array}$ & CD163, CD206, Fizzl, & IL-I0, TGF-B, IGF- I, & $\begin{array}{c}\text { CCL- } \\
8 / 17 / 18 / 22 / 24\end{array}$ & $\begin{array}{l}\text { Anti-inflammatory } \\
\text { function }\end{array}$ \\
\hline & Tregs,BM-MSC, & YmL/2, RELM- $\alpha$, arginase-I, & PGE-2 & & $\begin{array}{l}\text { Phagocytosis tissue } \\
\text { remodeling, }\end{array}$ \\
\hline & ADSCs, IDO & PPAR-delta, SRA-I TLRI/8 & & & Fibrosis \\
\hline
\end{tabular}

Notes: MI cells are classically activated macrophages: alternatively activated macrophages (M2 cells) can be divided into subtypes of M2a, M2b, and M2c. Abbreviations: LPS, lipopolysaccharide,; GM-CSF, granulocyte- macrophage colony-stimulating factor, LDL low -density lipoprotein; HMGBI, high- mobility group box I; iNOS, inducible nitric oxide synchase; Tregs, regulatory T cells; ADSCs, adipose tissuederived stromal cells; IDO, indoleamine 23-dioxygenease, PPAR, perixome prolfelator-acttivated receptor A-I; pge2, prostaglandin E2.

Source: Macrophages Clinical and Diagnostic Laboratory Test Result of Gatot Soebroto Central Army Hospital 